\title{
A NOVEL APPROACH TO THE FINANCIALIZATION OF REAL SECTOR
}

DOI: 10.17261/Pressacademia.2021.1461

JBEF-V.10-ISS.4-2021(2)-p.157-165

Bulent Hoca

Istanbul Okan University, Department of International Trade, Tuzla Campus, Istanbul, Turkey. bulent.hoca@okan.edu.tr, ORCID: 0000-0001-9093-9887

\begin{tabular}{|c|c|c|}
\hline Date Received: September 5, 2021 & Date Accepted: December 15, 2021 & OPEN $\odot$ ACCESS \\
\hline
\end{tabular}

To cite this document

Hoca, B., (2021). A novel approach to the financialization of real sector. Journal of Business, Economics and Finance (JBEF), 10 (4), 157-165.

Permanent link to this document: http://doi.org/10.17261/Pressacademia.2021.1461

Copyright: Published by PressAcademia and limited licensed re-use rights only.

\section{ABSTRACT}

Purpose- Finance is a very important sector both for real sector, economic growth and development, and as a potential source of instability. The relatively new term of financialization is used to denote the increasing role of finance in the economy. In this context, our main purpose is to make a novel contribution to the explanation of the financialization of the real sector. Literature points out the profitability problem of real sector in the crisis of 1970s and ensuing political, legal and institutional changes described as neo-liberalism. Hence, we investigate the relationship between profit rate and financialization of real sector and we argue a long-term relationship between them that goes beyond the crisis of 1970 s. Methodology- We constructed profit rate series and financialization series starting from 1948 for real sector in the USA, because it is the country providing the longest and most detailed data. Since the series are integrated of different orders, the ARDL Bounds Test approach is used to test the long-term relationship between profit rate and ratio of financial assets in total assets as a measure of financialization.

Findings- The results indicate that there is a long-term relationship between financialization and profit rate. Also, the relationship is negative. Thus, profit rate decreases are related to increased ratio of financial assets in total assets in long-term.

Conclusion- Our results imply that confronting profitability problem real sector directs its sources to finance. Despite the common view in the literature that this relation has started around 1970s, our analysis indicate that this relationship goes beyond the changes that took place in 1970 s or 1980s which are considered as leading to neoliberalism.

Keywords: Financialization, profit rate, real sector, political economy, Bounds test JEL Codes: B51, 016, P16

\section{INTRODUCTION}

Financialization is a relatively new term. The literature on financialization goes back to early 2000s (Goldstein, 2009), so it is almost two decades old. The term came out of heterodox economics literature, gained popularity and essentially reflects the ascendancy of finance (Lapavitsas, 2013). As Gerald Epstein, a leading political economist at University of Massachusetts Amherst who edited a pioneering book about financialization, denotes, financialization is seen as one of the most important dimensions of not only numerous financial crises but also a whole recent period, which is called globalization or neo-liberalism period:

“...[S]ometime in the mid- to late 1970s or early 1980s, structural shifts of dramatic proportions took place in a number of countries that led to significant increases in financial transactions, real interest rates, the profitability of financial firms, and the shares of national income accruing to the holders of financial assets. This set of phenomena reflects the processes of financialization in the world economy." (Epstein, 2005: 4)

The term of financializaton is used to refer to several indicators: "Financialisation, refers to the increasing dominance of the finance industry in the sum total of economic activity, of financial controllers in the management of corporations, of financial assets among total assets, of marketed securities, and particularly of equities, among financial assets, of the stock market as a market for corporate control in determining corporate strategies, and of fluctuations in the stock market as a determinant of business cycles." (Dore, 2002: 116-117). 
While Epstein (2005) provides evidence of financialization in terms of increasing rentier share in national incomes in several countries (e.g., in the US from $16.93 \%$ in 1960 s to $35.24 \%$ in 1990 s), and Orhangazi (2008) points out the increasing ratio of financial income in national income in the USA (from 12 and 14\% in the 1952-1980 period to 20\% in 2000s), Philippon in his American Economic Review article demonstrates historically highest levels of share of financial sector in GDP in 2000s in the USA with a dataset he constructed starting from 1859 (Philippon, 2015).

Although financialization is important and several explanations of it have been suggested so far, according to Costas Lapavitsas, a leading political economist at University of London, "to be sure the concept is still raw and undeveloped, but its power cannot be denied" (Lapavitsas, 2011: 611). This study specifically prefers to concentrate on the financialization of the real sector and suggests an explanation. More clearly, the purpose of this study is to provide a novel and econometrically tested explanation of this type of financialization, and to contribute to the clarification of the term. It shows that beyond recent neo-liberal period there is a longrun relationship between profit rate and financialization using a constructed dataset starting from 1948 . The rest of the paper is organized as section 2 gives a brief information about related literature of explanations of financialization. In section 3 , we introduce data and chosen methodology of econometrics briefly. Section 4 introduces econometric analysis results. In Section 5 we conclude and summarize important outcomes of the paper.

\section{LITERATURE REVIEW}

Several explanations of financialization have been proposed so far. Despite their variations, they relate financialization to the crisis of 1970s and ensuing successful implementation of neo-liberal policies. For example, according to David Harvey, a leading political economist and geographer who was among the top 20 most cited author in humanities in 2007 (Times Higher Education, 2009), there are two main reasons of financialization. One reason is the overaccumulation crisis of capital in 1970s and the US response to the crisis (Harvey, 2003: 62): "Threatened in the realm of production, the US had countered by asserting its hegemony through finance". The other reason is struggle of capitalist class for restoring its power after 1970s, of which financialization is the first component (Harvey, 2005).

Likewise, Dumenil and Levy, two French economists at CEPREMAP (Center for Economic Research and its Applications) in Paris, sees financialization as a result of a class struggle of finance capital that was heightened by the crisis of 1970s (Dumenil and Levy, 2005). Another explanation provided by Lapavitsas (2009) relates financialization also to the 1970 s crisis and ensuing political, institutional changes like deregulation of financial markets, and technological changes. Lapavitsas (2013) specifically places the start of financialization in the late 1970 s as well.

Paul Sweezy, an economist well-known with his kinked-demand model of oligopoly, also sees financialization as a reflection of the problems in the real sector that were stiffened in the 1970s. For example, Sweezy (1994) explains financialization with the stagnation that reemerged in the 1970s: "they [oligopolists] should invest in financial, not real productive assets. And that, I think, is just what they began to do on an increasing scale as the economy sank once again into stagnation in the 1970s."

Samir Amin (2011: 28), a pioneer of Dependency theory in development economics, explains financialization by two contingent factors pertaining to neoliberalism: "This financialisation has been made possible both by the generalization of the flexible exchange system (the rates of which are determined each day by what is called "the market") and by the parallel deregulation of the rates of interest (also abandoned to supply and demand)." He adds that the oligopolies deliberately chosen financialization path for the system as a whole.

Analyzing these and some other studies Orhangazi (2008: 56) concludes that "the rise of the financialized neoliberal regime was not necessarily the only available road following the accumulation crisis of the 1970s but it was in many aspects the result of deliberate policy interventions in the benefit of the wealthier capitalists".

Indeed, at first glance globalization, concurrent neo-liberal financial deregulation policies and soaring financial transactions might give the impression that financialization started with them and the start was in the 1970s. It seems that financialization was a new and contingent response of capital to profitability problems. However, some factors lead us to argue that there can be an inner and structural relationship between profitability problems and financialization beyond 1970s crisis. First of all, profitability problems in the real sector are not specific to 1970s. Profit rate data constructed by us given below in Figure 3 supports this argument. Secondly, long-term data provided by Philippon (2015) shown in Figure 1 points out an increase in financialization measured as share of financial sector in national income in the USA long before 1970s. 
Figure 1: GDP Share of Finance

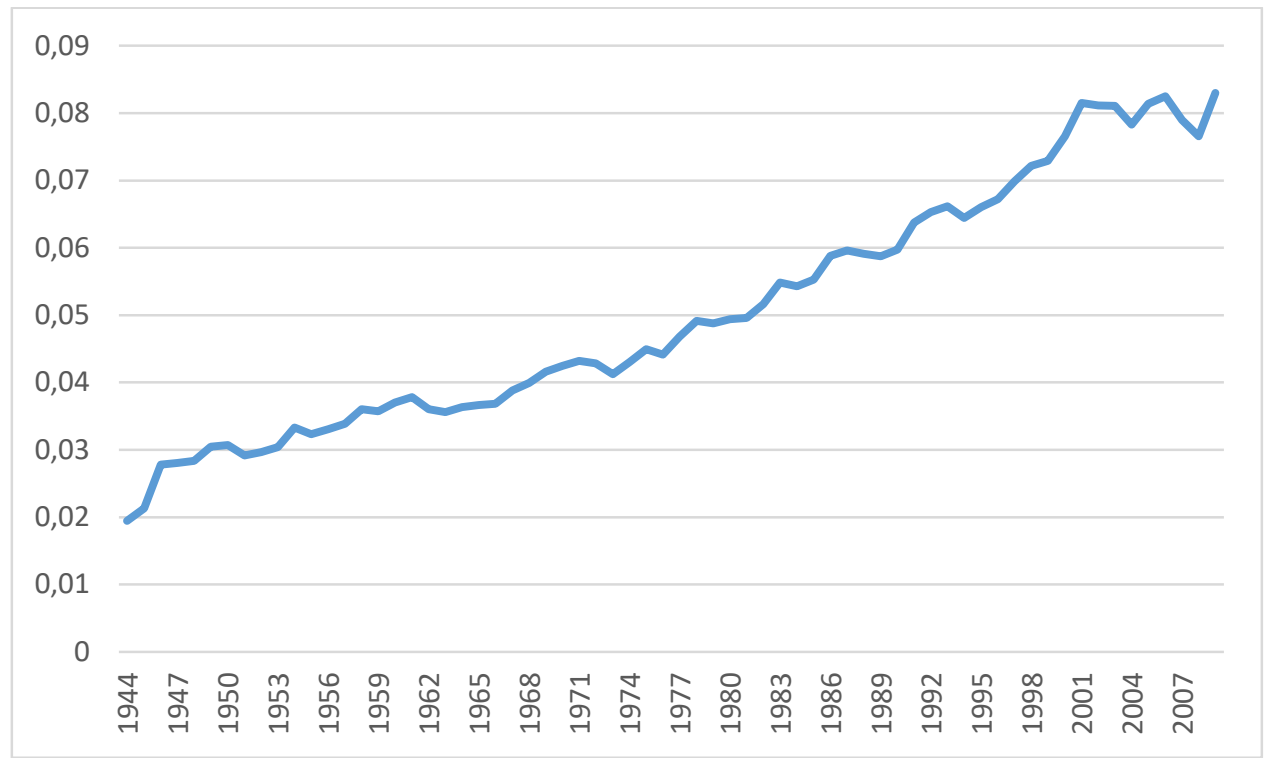

Source: Philippon (2015)

Thirdly, as Hoca argues in his Cambridge Journal of Economics article (Hoca, 2012), there are theoretical grounds to suggest a long-term relationship related to the functioning of capitalism. Especially finance is a force for the centralization of capital, acceleration of capitalist development especially by providing the necessary funds for big real investments, and hence overcoming the existing barriers of real capital accumulation in capitalism. Starting from railroad industry, large-scale investments have usually required the involvement of force of finance.

At the same time finance has a speculative aspect and can become a source of instability so we frequently see calls for curbing it. Actually, finance was restrained somewhat first during the New Deal after the Great Depression, and then during the following Keynesian period right after the Second World War (Golden Age) (Orhangazi, 2008). However, it did not take long to regain its importance in the 1960s, as epitomized with the rise of the Eurodollar market: "Beginning in the late 1950s ... private international financial activity increased at a phenomenal rate" (Helleiner, 1994: 1).

\section{DATA AND METHODOLOGY}

The variable we try to explain is financialization of the real sector and the explanatory variable we suggest is profit rate of the real sector. Because we suggest a long-run relationship between financialization and profit rate rather than a contingent relationship for a recent specific period, to investigate the existence of this long-run relationship we constructed two-time series for financialization and profit rate as long as possible. Since longest time series data is provided in the case of USA, only the USA data is considered.

\subsection{Financialization Data}

To calculate the financialization of real sector, the total financial assets of nonfinancial corporate business is divided by total assets of this sector. Hence, it is the ratio of total financial assets in total assets. Both total financial assets and total assets are given for nonfinancial corporate business by Fed. Total financial assets is the most general indicator of financial involvement of the real sector. Data is taken from the Financial Accounts of the United States - Z.1 of Fed, which starts in 1945, and logarithmic transformation is applied as shown in Figure 2. As will be explained below, since profit rate data can only be calculated after 1948, financialization data is also started in this year. Despite some ebbs and flows, an upward historical trend from the beginning can be discerned. 
Figure 2: Financialization in Nonfinancial Corporate Business of USA (logarithmic) (LRFA)

\section{LRFA}

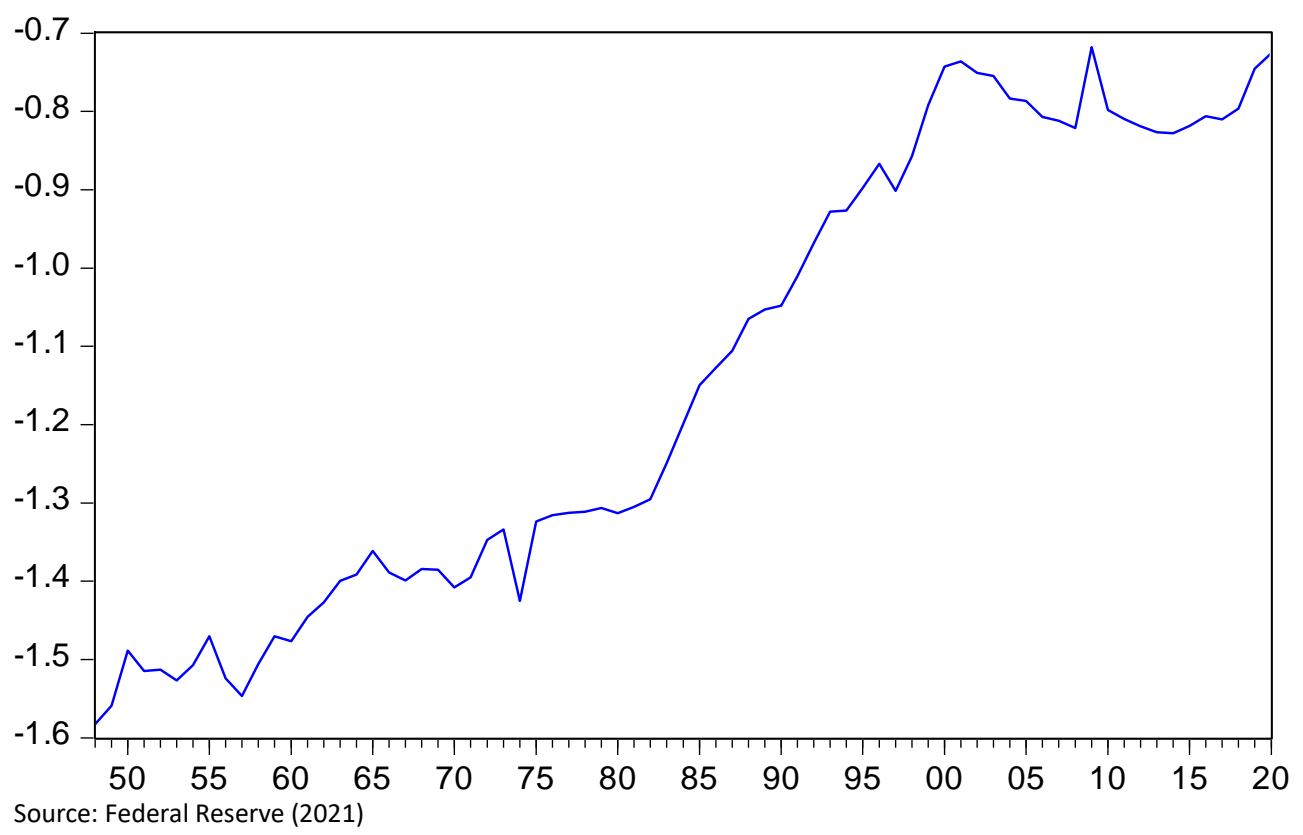

\subsection{Profit Rate Data}

For the definition of profit rate, heterodox approach of Guglielmo Carchedi, a leading heterodox economist at University of Amsterdam, in his book (2018) is followed. Only those sectors that are considered to be productive (surplus-value producing) real sector by Carchedi (2018) are included in the calculation of profits, namely: Agriculture, forestry, and fishing, Mining, Construction and Manufacturing. Profits are corporate profits before tax taken from Bureau of Economic Analysis (BEA) National Income and Product Accounts (NIPA) Tables 6.17A, 6.17B, 6.17C and 6.17D. To get the profit rate, profits are divided by capital invested. In the calculation of capital invested, two components of capital are considered: Fixed and Variable. For variable capital, Wages and Salaries of Goods Producing Industries are taken from NIPA Table 2.2A and 2.2B of BEA and for fixed capital, Historical-Cost Net Stock of Private Fixed Assets in aforementioned industries are taken from Fixed Assets by Type Table 3.3ESI of BEA, which are only provided for after 1947. However, because temporalist approach of Carchedi requires profits to be divided by the previous year's capital, profit rate series start in 1948. Logarithmic transformation is applied and shown in Figure 3. As mentioned above, profit rate decline goes back to long before 1970s. A downward trend is clearly discernible since 1950 s. 
Figure 3: Profit Rate in Nonfinancial Corporate Business of USA (logarithmic) (LPR)

\section{LPR}

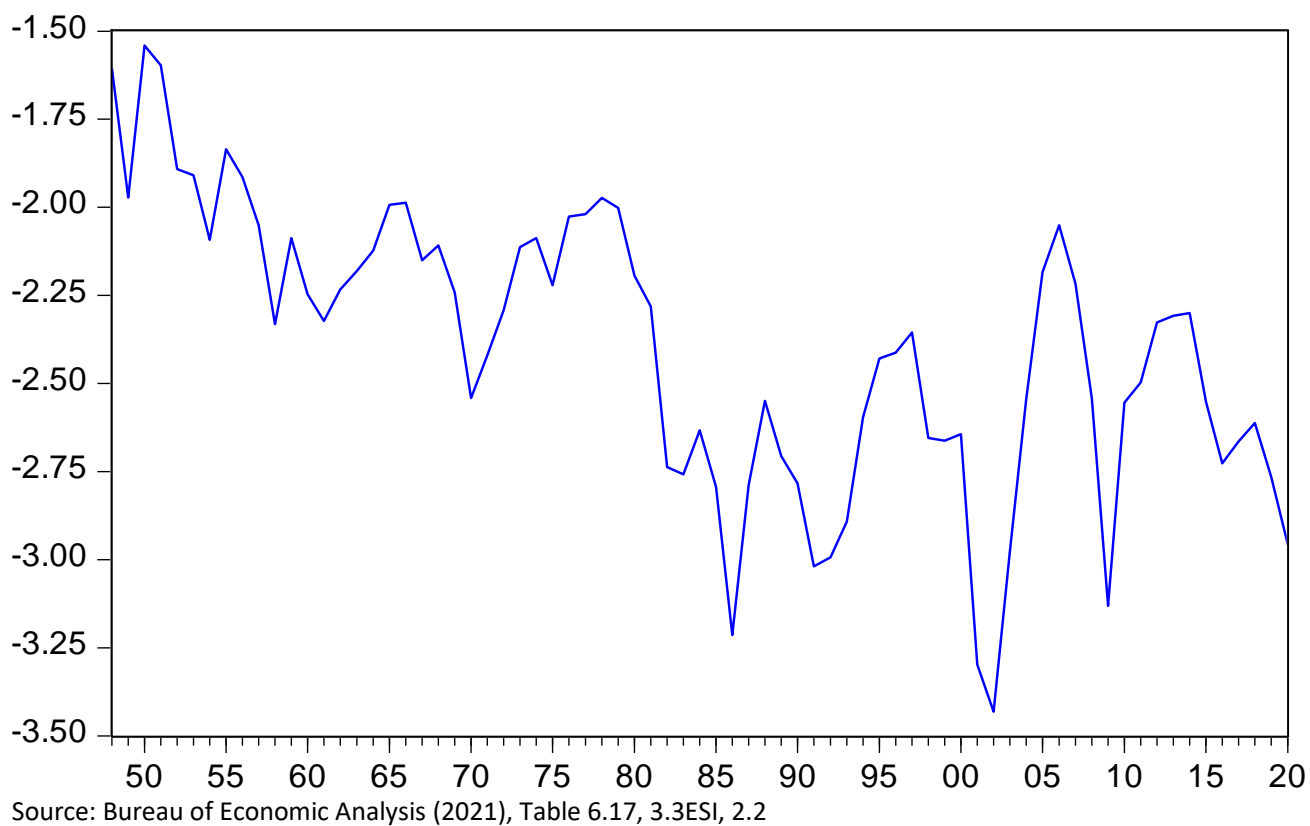

\subsection{Econometric Methodology}

To test the existence of long-run relationships such as the one we are looking in this paper, the literature often uses Johansen cointegration test. However, this and other cointegration methods requires that "the underlying variables are integrated of order one", I(1) (Pesaran, Shin and Smith, 2001, p.289). Pesaran, Shin and Smith (2001) offers, instead, ARDL Bounds Test to test longrun relationships, which allows variables to be integrated of different orders like I(0) or I(1), except I(2).

Related unit root test results with intercept and trend from Eviews 9 are given below in Table 1 and 2. Profit rate series (LPR) constructed above is trend stationary in level (hence, $\mathrm{I}(0)$ ) and this reinforces our argument above that profitability problem is earlier than 1970s.

Table 1: Unit Root Tests for LPR

\begin{tabular}{|l|l|}
\hline ADF Test & Phillips-Perron Test \\
\hline$-3.982652 *(p=0.0136)$ & $-3.614491 *(p=0.0355)$ \\
\hline
\end{tabular}

*The null hypothesis that LPR has a unit root is rejected at $5 \%$.

On the other hand, ratio of financial assets (LRFA) is not stationary in level as shown below in Table 2.

Table 2: Unit Root Tests for LRFA

\begin{tabular}{|l|l|}
\hline ADF Test & Phillips-Perron Test \\
\hline$-1.735876^{*}(p=0.7250)$ & $-1.658416^{*}(p=0.7594)$ \\
\hline
\end{tabular}

*The null hypothesis that LPR has a unit root is not rejected at $5 \%$.

However, LRFA becomes intercept and trend stationary at first difference as shown below in Table 3, hence I(1). 
Table 3: Unit Root Tests for D(LRFA)

\begin{tabular}{|l|l|}
\hline ADF Test & Phillips-Perron Test \\
\hline$-9.091878 *(p=0.0000)$ & $-9.097898 *(p=0.0000)$ \\
\hline
\end{tabular}

* The null hypothesis that LPR has a unit root is rejected at $1 \%$.

These results show that LPR is I(0) and LRFA is I(1). This leads us to use ARDL Bounds Test as econometric method to investigate the existence of long-run relationship between them.

\section{FINDINGS AND DISCUSSIONS}

Eviews can automatically select the appropriate number of lags for each variable in ARDL model. Using Akaike Information Criterion Eviews picks ARDL model with three lags for LFRA and zero lag for $\operatorname{LPR}$, hence $\operatorname{ARDL}(3,0)$.

Diagnostic tests of the selected ARDL model are shown below in Table 4. By failing to reject null hypothesis of no serial correlation, Breusch-Godfrey Serial Correlation LM Test shows evidence that there is no serial correlation in the model. By failing to reject null hypothesis of no heteroskedasticity, Breusch-Pagan-Godfrey Test supports no heteroskedasticity. By failing to reject null hypothesis of correct specification, Ramsey RESET test gives evidence that model form is correct.

Table 4: Diagnostic Tests of ARDL Model

\begin{tabular}{|l|c|c|c|}
\hline & LM Test & Breusch-Pagan-Godfrey Test & Ramsey RESET Test \\
\hline Test statistic & 0.206029 & 0.224248 & 2.240458 \\
\hline p-value & 0.8919 & 0.9239 & 0.1394 \\
\hline
\end{tabular}

Two more diagnostics test result about stability of the model provided below in Figure 4 and 5 support the stability of the ARDL model.

\section{Figure 4: CUSUM Stability Test of ARDL Model}

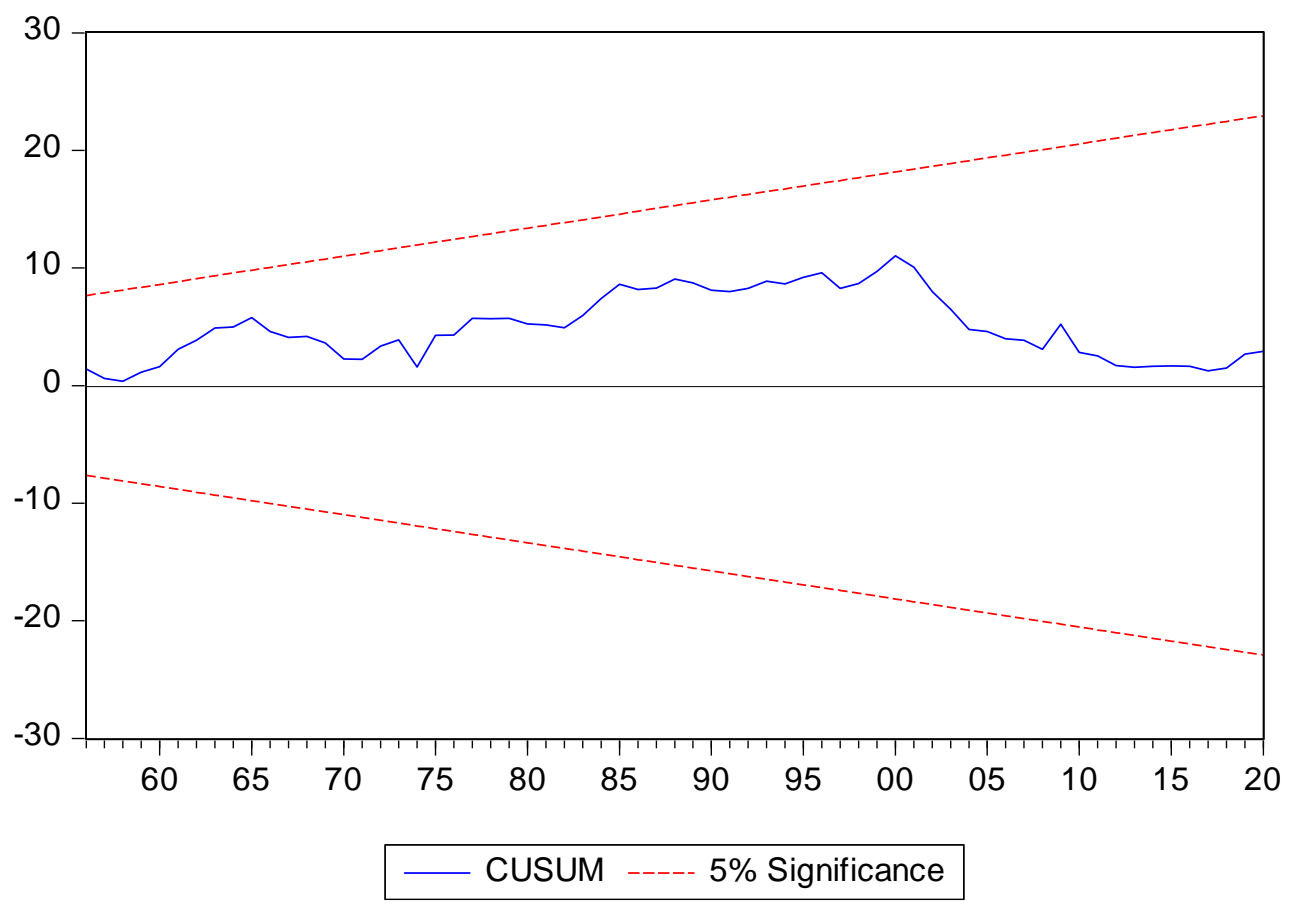


Figure 5: CUSUM of Squares Stability Test of the ARDL Model

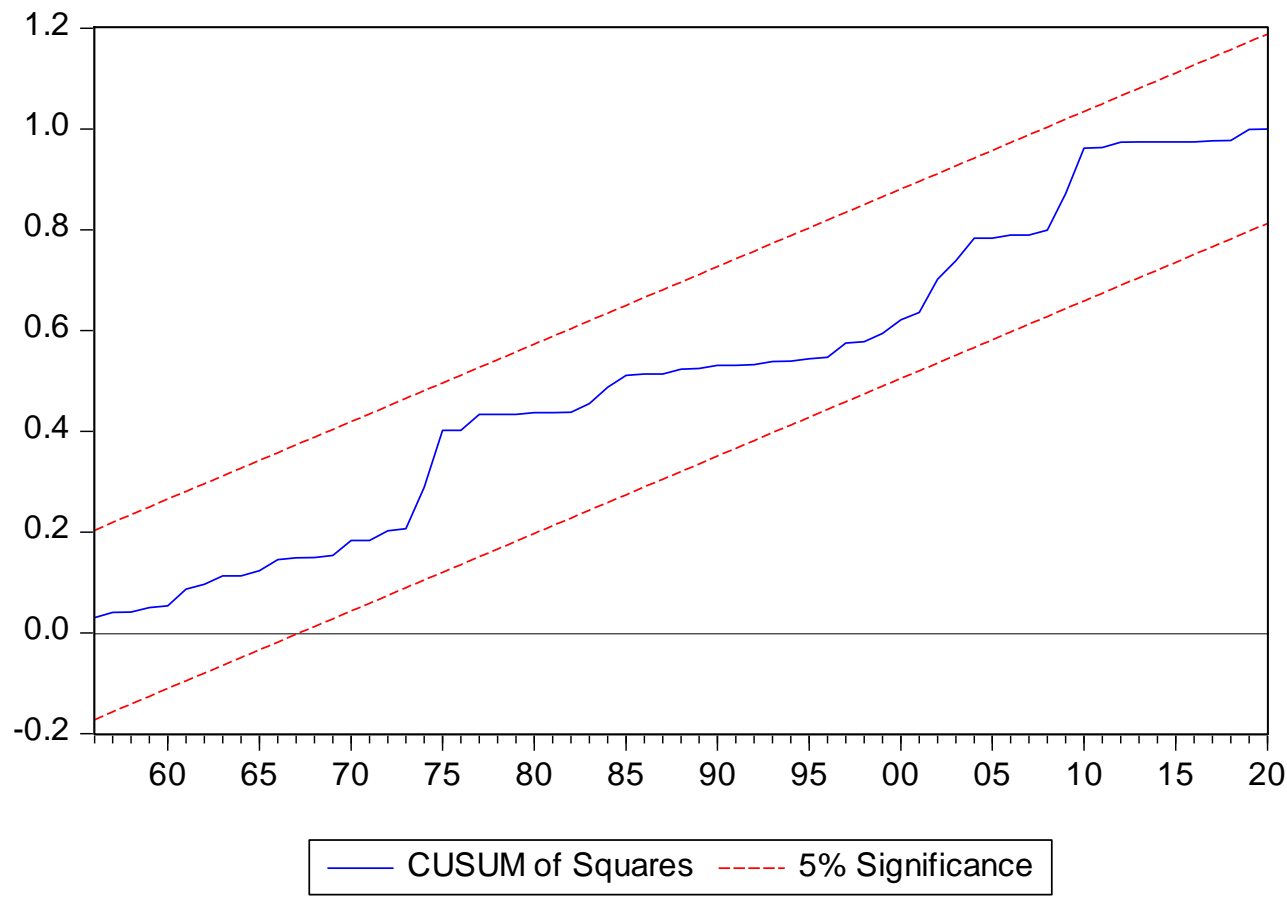

As given below in Table 5, Bounds test applied to this model shows that F-statistic is beyond upper bound critical value at $2.5 \%$ significance and null hypothesis of no long-run relationship exist is rejected. Thus, this supports the existence of the long-run relationship. These two variables are cointegrated at $2.5 \%$ significance level.

\section{Table 5: ARDL Bounds Test}

\begin{tabular}{|l|l|l|}
\hline Test Statistics & Value & k \\
\hline F-statistic & 5.545573 & 1 \\
\hline Critical Value Bounds \\
\hline Significance & I0 Bound & I1 Bound \\
\hline $10 \%$ & 3.02 & 3.51 \\
\hline $5 \%$ & 3.62 & 4.16 \\
\hline $2.50 \%$ & 4.18 & 4.79 \\
\hline $1 \%$ & 4.94 & 5.58 \\
\hline
\end{tabular}

In addition, the long-run coefficients of the selected ARDL model, which is given below in Table 6 .

Table 6: Long Run Coefficients

\begin{tabular}{|l|l|l|l|l|}
\hline Variable & Coefficient & Std. Error & t-Statistic & Prob. \\
\hline LPR & -1.14965 & 0.302242 & -3.80374 & 0.0003 \\
\hline C & -3.59675 & 0.657789 & -5.46794 & 0.0000 \\
\hline
\end{tabular}

Coefficients in Table 6 are significant and LPR has a negative coefficient. This negative relation is expected by our argument because parallel to the literature we suggested financialization is related to the profitability and hence to capital accumulation problems of real sector. 


\section{CONCLUSION AND IMPLICATIONS}

Financial system and its products are very crucial both for their role in economic development and as a source of instability in the economy as seen in the recent mortgage crisis of 2008. In addition, as pointed out by financialization literature and our data, finance is increasing its role. Our results indicate that confronting profitability problem real sector directs its sources to finance. Despite the common view that this relation has started around 1970s, our analysis imply that this relationship goes deeper than political choices or struggles, legal and institutional changes that took place in 1970s or 1980s which are considered as leading to neo-liberalism. This is not to deny the role of these struggles or changes. However, understanding economic relationships underpinning these just as important as. We hope that this study is a contribution to this end: "A common theme in the literature is the role of the accumulation crisis of the 1970s. Many in the literature argue that financialization, together with liberalization and deregulation, was a response to this crisis. However, there are not many studies that theoretically or empirically discuss the relationship between capital accumulation and financialization." (Orhangazi, 2008, 131).

This long-term relationship can have implications both for real sector and financial sector and bring up questions for further studies, upon which we can only touch here. Is there a way other than financialization that real sector can confront profitability problems? Are more regulations possible on the side of financial sector which increasingly attracts the resources from real sector? These questions are on the agenda especially following the mortgage crisis of 2008.

\section{ACKNOWLEDGEMENTS}

I would like to thank Prof. Dr. Elçin Aykaç Alp at Istanbul Commerce University for her helpful comments. All the usual caveats apply.

\section{REFERENCES}

Amin, S., (2011). Ending the crisis of capitalism or ending capitalism? Oxford: Pambazuka Press, ISBN: 978-1-906387-80-8 paperback

Bureau of Economic Analysis, (2021). National Economic Accounts, https://www.bea.gov/data/economic-accounts/national (Date Accessed: September 15, 2021)

Carchedi, G., (2018). The Old Is Dying but the New Cannot Be Born: On the Exhaustion of Western Capitalism. In: World in Crisis. G. Carchedi ve M. Roberts (eds), Haymarket Books, Chicago, ISBN-10: 1608461815

Epstein G.A., (2005). Introduction: Financialization and the world economy. In: Financialization and the World Economy, Epstein GA, (ed). Cheltenham: Edward Elgar, 3-16, ISBN: 1843768747

Dore, R. (2002). Stock market capitalism and its diffusion. New Political Economy, 7(1): 115-121

Dumenil, G., and Levy, D., (2005). Costs and benefits of neoliberalism: a class analysis. In: Financialization and the World Economy, Epstein GA, (ed). Cheltenham: Edward Elgar, 17-45, ISBN: 1843768747

Federal Reserve, (2021). Financial Accounts of the United States - Z.1, https://www.federalreserve.gov/datadownload/Build.aspx?rel=z1 (Date Accessed: September 20, 2021)

Goldstein, J.P., (2009). Introduction: The political economy of financialization. Review of Radical Political Economics, $41(4)$, $453-457$.

Harvey, D., (2003). The new imperialism. Oxford: Oxford University Press, ISBN-10: 9780199278084

Harvey, D. (2005). A brief history of neoliberalism. Oxford: Oxford University Press, ISBN-10: 0199283273

Helleiner, E. (1994). States and the reemergence of global finance: from Bretton Woods to the 1990s. Ithaka: Cornell University Press, ISBN: 08014-8333-6 (paper)

Hoca, B., (2012). A suggestion for a new definition of the concept of finance capital using Marx's notion of 'capital as commodity'. Cambridge Journal of Economics 36(2): 419-434

Lapavitsas, C., (2009). Financialised capitalism: crisis and financial expropriation. Historical Materialism 17(2): 114-148.

Lapavitsas C., (2011). Theorizing financialization. Work, Employment and Society. 25(4): 611-626.

Lapavitsas, C., (2013). Profiting Without Producing. Verso Books, New York, ISBN: 9781781681411 (paperback)

Orhangazi, Ö., (2008). Financialization and the US economy. Cheltenham: Edward Elgar, ISBN: 9781847205940

Pesaran, M.H., Shin, Y., Smith, R.J. (2001). Bounds Testing Approaches to the Analysis of Level Relationships. Journal of Applied Econometrics, 16(3), 289-326. 
Philippon, T., (2015). Has the US Finance Industry Become Less Efficient? On the Theory and Measurement of Financial Intermediation. American Economic Review, 105(4): 1408-38.

Sweezy, P., (1994). The Triumph of Financial Capital. Monthly Review, 46(02), http://monthlyreview.org/1994/06/01/the-triumph-of-financialcapital\#top (Date Accessed: October 20, 2021)

Times Higher Education, (2009). Most cited authors of books in the humanities, 2007 [online], Data provided by Thomson Reuters' ISI Web of Science, 2007, https://www.timeshighereducation.com/news/most-cited-authors-of-books-in-the-humanities-2007/405956.article (Date Accessed: October 24, 2021) 